\title{
Adolescents in southern Africa: Interdisciplinary research findings
}

Adolescent development in sub-Saharan Africa is relevant because this population will transition into the region's future leaders and parents. However, adolescents face a number of challenges, including social, economic and health difficulties, which prohibit their successful transition to adulthood. Also, given the transitional nature of this age group, there is a need to understand a labyrinth of determinants, influences and outcomes, and to address all possible challenges and inhibitors to their development.

This special issue contains 15 research papers on adolescent health and development across sub-Saharan Africa from various disciplines within the social sciences. This interdisciplinary approach offers fresh perspectives from multiple disciplinary paradigms. The contributors to this special issue are leading researchers in their respective fields, and more importantly, some are early career academics, including Master of Arts and doctoral students. We specifically sought to include young scholars because for emerging African scholars, learning to make connections between theory, concepts and methods across disciplines enables them to apply their discipline-specific knowledge, and also to gain a deeper understanding of other disciplines, which strengthens the overall learning experience and skills development.

There are four main themes presented in this special issue: schooling; sexual and reproductive health knowledge; sexual and reproductive health outcomes; and other health and social challenges. Under the theme of 'schooling', three South African (SA) papers have identified major challenges for adolescents. Fotso et al ${ }^{[1]}$ found that progression to the next grade was low among adolescents who had HIV, and that HIV-positive pupils struggled to complete school. Mabetha and De Wet ${ }^{[2]}$ found that experiences of peer- and teacherperpetrated school-based sexual harassment are associated with non-condom use among 10 - 19-year-olds, and Pillay ${ }^{[3]}$ argues that school incompletion for recent adolescent mothers is due to financial and childcare constraints.

Four papers in this special issue identified areas of concern in relation to sexual and reproductive health knowledge among young people in SA. First, Evans et al. ${ }^{[4]}$ found that more than half of university students lack accurate and sufficient TB and HIV knowledge, while Tolla et al ${ }^{[5]}$ found that young adolescents were not naive, and had knowledge of sexually transmitted diseases, but struggled to navigate sexual relationships on their own. Essop et al. ${ }^{[6]}$ argue that both formal and informal sexual education are advantageous to young adolescents, and Brown et al. ${ }^{[7]}$ are promoting the testing and implementation of cultural consensus modelling to better understand the reproductive needs of young girls.

Related to knowledge is the theme of 'sexual and reproductive health outcomes'. Odimegwu et al. ${ }^{[8]}$ found that low levels of education increased the odds of young men (aged $12-22$ years) becoming adolescent fathers. Furthermore, Odimegwu and Frade $e^{[9]}$ haveidentified a pathway that exists between early age at cohabitation and increased risk of intimate partner violence among young women in Uganda. Groenewald et al. ${ }^{[10]}$ identified risky sexual behaviours among adolescents using a photovoice methodology that allows adolescents to speak through pictures of their experiences.

However, adolescents do not only face sexual and reproductive health challenges, but are also dealing with other diseases including cancer, respiratory-tract infections and mental-health conditions, including depression. Under the final theme of the articles, Letuka and De Wet's ${ }^{[11]}$ results show that young women in Lesotho are screening for cervical cancer at much younger ages than prescribed by the World Health Organization. De Wet and Frade ${ }^{[12]}$ found that episodes of disease, including respiratory-tract infections and asthma, are contributing to grade repetition among schoolgoing adolescents. The paper by Ajaero et al. ${ }^{[13]}$ shows that urban-based adolescents are more likely to suffer depression than their rural counterparts. The paper by Moroe and de Andrade ${ }^{[14]}$ speaks to the challenges that adolescents with disabled parents face in attempting to assist them with various interactions. Finally, Olawole-Isaac et $a l^{[15]}$ conducted a systematic review of recent publications and found that substance abuse was high among adolescents across sub-Saharan Africa.

It is with great pride and pleasure that we publish this special issue of important research. However, this publication would not have been possible without the funding from the DST/NRF Centre of Excellence in Human Development. We are also grateful to the editor of SAJCH, Prof. John Pettifor, the managing editor, Claudia Naidu, all the peer-reviewers and the copyediting team at the $\mathrm{SAJCH}$.

\section{Nicole De Wet, $\mathrm{PhD}$}

Demography and Population Studies, Schools of Public Health and Social Sciences, Faculties of Health Sciences and Humanities, University of the Witwatersrand, Johannesburg, South Africa nicole.dewet@wits.ac.za

\section{S Afr J Child Health 2018;12(2 Suppl 1):S2-S3. DOI:10.7196/SAJCH.2018.v12i2.1590}

1. Fotso AS, Banjo O, Akinyemi JO. HIV and adolescents' educational attainment in South Africa: Disentangling the effect of infection in children and household members. S Afr J Child Health 2018;12(2 Suppl 1):S4-S9. https://doi. org/10.7196/SAJCH.2018.v12i2.1590

2. Mabetha K, De Wet N. Sexual harassment in South African schools: Is there an association with risky sexual behaviours? S Afr J Child Health 2018;12(2 Suppl 1):S10-S14. https://doi.org/10.7196/SAJCH.2018.v12i2.1526

3. Pillay N. Pathways to school completion for young mothers: Are we winning the fight? S Afr J Child Health 2018;12(2 Suppl 1):S15-S18. https://doi.org/10.7196/ SAJCH.2018.v12i2.1530

4. Evans D, Musakwa N, Nattey C, et al. Knowledge, risk perception and access to healthcare services for HIV and tuberculosis among university students in Johannesburg, South Africa. S Afr J Child Health 2018;12(2 Suppl 1):S19-S31. https://doi.org/10.7196/SAJCH.2018.v12i2.1525

5. Tolla T, Essop R, Fluks L, Lynch I, Makoae M, Moolman B. Too young to have sex: Conversations with very young adolescents about sex, dating and related decision-making. S Afr J Child Health 2018;12(2 Suppl 1):S32-S35. https://doi. org/10.7196/SAJCH.2018.v12i2.1519

6. Essop R, Tolla T, Lynch I, Makoae M. 'They tell you about the risks': Exploring sources of sexuality education among very young adolescents in rural Mpumalanga. S Afr J Child Health 2018;12(2 Suppl 1):S36-S39. https://doi. org/10.7196/SAJCH.2018.v12i2.1527

7. Brown JL, Sales JM, Sharp C, et al. Cultural consensus modelling to understand the reproductive health needs of South African adolescent girls. S Afr J Child Health 2018;12(2 Suppl 1):S40-S44. https://doi.org/10.7196/SAJCH.2018. v12i 2.1500

8. Odimegwu CO, Amoo EO, De Wet N. Teenage pregnancy in South Africa: Where are the young men involved? S Afr J Child Health 2018;12(2 Suppl 1):S45-S51. https://doi.org/10.7196/SAJCH.2018.v12i2.1523

9. Odimegwu CO, Frade S. The influence of adolescent age at first union on physical intimate partner violence and fertility in Uganda: A path analysis. S Afr J Child Health 2018;12(2 Suppl 1):S52-S57. https://doi.org/10.7196/ SAJCH.2018.v12i2.1498

10. Groenewald C, Essack Z, Khumalo S. Speaking through pictures: Canvassing adolescent risk behaviours in a semi-rural community in KwaZulu-Natal Province, South Africa. S Afr J Child Health 2018;12(2 Suppl 1):S58-S63. https://doi.org/10.7196/SAJCH.2018.v12i2.1514

11. Letuka T, De Wet N. Cervical cancer screening among adolescent girls in Lesotho: Levels and determinants. S Afr J Child Health 2018;12(2 Suppl 1):S64-S67. https://doi.org/10.7196/SAJCH.2018.v12i2.1518 
12. De Wet N, Frade S. Disease prevalence and grade repetition among adolescents in South Africa: Is there any relationship? S Afr J Child Health 2018;12(2 Suppl 1):68-71. https://doi.org/10.7196/SAJCH.2018.v12i2.1504

13. Ajaero CK, Nzeadibe CT, Igboeli EE. Rural-urban differences in the prevalence and predictors of depression among adolescents in South Africa. S Afr J Child Health 2018;12(2 Suppl 1):S72-S75. https://doi.org/10.7196/SAJCH.2018. v12i2.1509
14. Moroe NF, de Andrade V. 'We were our parents' ears and mouths': Reflecting on the language brokering experiences of hearing children born to deaf parents. S Afr J Child Health 2018;12(2 Suppl 1):S76-S79. https://doi.org/10.7196/ SAJCH.2018.v12i2.1524

15. Olawole-Isaac A, Ogundipe O, Amoo EO, Adeloye D. Substance use among adolescents in sub-Saharan Africa: A systematic review and meta-analysis. S Afr J Child Health 2018;12(2 Suppl 1):S80-S85. https://doi.org/10.7196/ SAJCH.2018.v12i2.1499 